\title{
BMPC 法における解領域と解領域更新新アルゴリズム
}

\author{
鳥 海 不二夫*・曹麗** \\ 大山真 司*小林涁*
}

Solution Domain of Band Function Model Paired Comparison Method

and New Algorithm for Solution Domain Renewal

Fujio TORIUmi* ${ }^{*}$ Li CAO**,

Shinji OHYAMA* and Akira KOBAYASHI*

\begin{abstract}
Band function model paired comparison (BMPC) method is effective for scaling of ambiguity quantity in the case such as sensory evaluation. The solution algorithm for BMPC method needs a large memory capacity and spents a lot of time. This reason is that the conventional method didn't utilize the functional relation between edge vectors and hyper planes on the solution domain. In this paper, we consider some natures of the inequalities to obtain solution domain and discuss about the edge vectors expressing solution domain. And we proposed the new effective algorithm to renewal solution domain based on the revealed natures of the inequalities. The new algorithm is examined and improved calculational performance are shown in the point of view of calculation time and memory capacities.
\end{abstract}

Key Words: paired comparison, sensory evaluation, solution domain,linear inequalities

\section{1. はじめに}

人間の感覚による曖昧量の計測，すなわち尺度付けにおい て比較的良い結果が得られる手法の一つに一対比較法がある. 一般的な一対比較法として Sheffé法や Thurstone 法がある が，それらの手法では，与えるべき尺度值の差と一対比較判 断結果の間の関係として直線性を仮定した比較判断モデルが 用いられる。

一方, 帯関数モデル型一対比較法 ${ }^{1) ~ 3) ~(B a n d ~ f u n c t i o n ~}$ model paired comparison method; 以下 BMPC 法と略記 する）は比較判断モデルを改良し, 直線性の仮定の替わりに 単調増加関係を仮定している. 寸なわち，人が比較判断する 際，与えるべき尺度值の差が大きい試料間の比較ほど判断は より明確になり大きな值の判断結果が得られるものと考え， さらに判断に飽和現象が現れる可能性も考慮してモデル化が なされている．また，人の判断には曖昧さがあり，ばらつき

* 東京工業大学大学院理工学研究科 東京都目黒区大岡川 2-12-1

** 中国 清華大学自動化系

* Graduate School of Science and Engineering, Tokyo Institute of Technology, Meguro-ku, Tokyo

** Department of Automation, Tsingha University, Beijing, CHINA

(Received October 18, 2000)

(Revised April 9, 2001)
も生じるので，単調増加関係に適当な幅を持たせた帯状の関 数で比較判断特性が表現されている。一方, 尺度付けに対応 する解を得る場合, 比較判断モデルの関数型を規定していな いため一対比較結果から解析的に解を直接得ることはできな いので, 単調増加関係を根拠として, 与えるべき尺度值の差 の間の大小関係から定まる不等式を利用し, 多数個の大小関 係から導かれる連立不等式を解くことにより解を求めている. 連立不等式から解が求められることに伴い, 解は一意でなく 領域として定まり，この解領域はその端点を意味する複数の 稜ベクトルを用いて記述されるが，ここに $\mathrm{BMPC}$ 法の大き な特徵が現れる。

BMPC 法のアルゴリズムは最終的に得られる解領域であ る凸包の端点列挙に帰着される。凸包端点列挙のすぐれた アルゴリズムとして D.Avis らによる Reverse Search ${ }^{4)}$ があ る.このアルゴリズムは与えら机た連立不等式に互いに矛盾 がなく解が凸包になることが明らかである場合, 非常に有効 なアルゴリズムである：しかし，BMPC法においては，一対 比較表から得られる連立不等式には矛盾する不等式が含まれ る可能性が高く，与えられた連立不等式から凸包がつくられ ることが保証されていない，そのため，不等式を選出しては 矛盾を起こさず，採用できるかどうかを判定しながら解領域 となる凸包を求める必要がある。そこで, BMPC 法のため の連立不等式の解法では, 解領域を逐次的に更新する解領域 更新法 ${ }^{2)}$,3)を用いている。ただし，この解法アルゴリズムに 
おいてこれまで多くのメモリ容量と計算時間を必要とし, 特

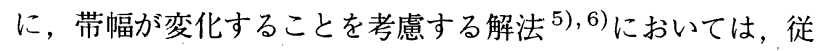
来よりも多くの不等式を用いて解を求めるためこの問題は深 刻となる。

本論文では解領域を求めるための不等式および解領域を記 述する稜ベクトルの特質を議論し；その特質を効果的に活用 する解領域更新新アルゴリズムを提案すると共に, 新アルゴ リズムによる計算はメモリ容量の点でも計算時間の点でもは るかに改善された性能を有することを明らかにする。

\section{BMPC 法の解領域更新アルゴリズムの概要 ${ }^{2)}$}

\section{1 連立不等式の導出 ${ }^{2)}$}

まず，各試料 $X_{i}(i=1,2, \cdots, n)$ があるとき，それぞれに 与えるべき尺度値を $m_{i}(i=1,2, \cdots, n)$ とし， $X_{i}$ の $X_{j}$ に 対する比較判断結果を $\varphi_{i j}$ とする.

最終的な目標は各試料に対し適切な尺度值 $m_{i}(i=$ $1,2, \cdots, n)$ を定めることにあるが, 直接入手できる情報 は $\varphi_{i j}$ だけである.そこで, BMPC 法では $\varphi_{i j}$ と $m_{i}, m_{j}$ との 間に次の関係があるものと考える.

$$
f_{d}\left(m_{j}-m_{i}\right) \leq \varphi_{i j} \leq f_{u}\left(m_{j}-m_{i}\right)
$$

ここで $f_{d}(x), f_{u}(x)$ は $x$ に関する適当な単調増加関数である.

問題は $\varphi_{i j}$ および式 $(1)$ を出発点として, 各試料の尺度 值 $m_{i}(i=1,2, \cdots, n)$ を求めることであるが, まず簡 単のため帯幅 $f_{u}(x)-f_{d}(x) \rightarrow 0$ となうた極限, つまり $f_{d}(x)=f_{u}(x)=f_{c}(x)$ として,

$$
\varphi_{i j}=f_{c}\left(m_{j}-m_{i}\right)
$$

の場合について考える。ここで, $f_{c}(x)$ が単調増加関数であ ることを考慮すると, 一対の $\varphi_{i j}, \varphi_{k l}$ の間の大小関係から,

$$
\begin{aligned}
\varphi_{i j}>\varphi_{k l} & \Longleftrightarrow f_{c}\left(m_{j}-m_{i}\right)>f_{c}\left(m_{l}-m_{k}\right) \\
& \Longleftrightarrow m_{j}-m_{i}>m_{l}-m_{k} \\
& \Longleftrightarrow m_{j}-m_{i}-m_{l}+m_{k}>0
\end{aligned}
$$

という $m_{i}, m_{j}, m_{k}, m_{l}$ に関する不等式を導出することがで きる。

$\varphi_{i j}$ のすべての対に対し式(3)のような不等式が得られるか ら，そ扎らを連立し，得ら机た連立不等式を解くことによっ て各試料の尺度值 $m_{i}(i=1,2, \cdots, n)$ が定められる.

次に $f_{u}(x)-f_{d}(x) \neq 0$ の場合, つまり判断にばらつきや 曖昧さがある場合について考える. (Fig. 1 参照)

このとき便宜上帯関数の幅を,

$$
\omega(x)=f_{u}(x)-f_{d}(x)
$$

と表わすことにすると, ある $\varphi_{i j}$ と $\varphi_{k l}$ との大小関係から間違 いのない $m_{i}$ に関する不等式が導出できるためには，

$$
\varphi_{i j}-\omega\left(m_{j}-m_{i}\right)>\varphi_{k l}
$$

が成り立つ必要がある。

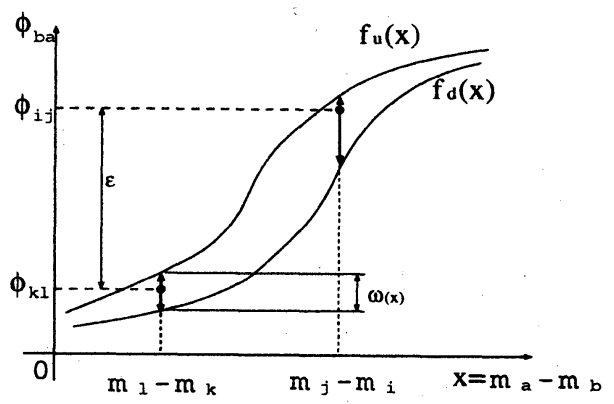

Fig. 1 Band function model

そこで非負の定数をを仮に採用し，式 (3) の代わりに

$\varphi_{i j}-\varepsilon>\varphi_{k l}$

$$
\Longleftrightarrow m_{j}-m_{i}-m_{l}+m_{k}>0
$$

により不等式を導出することとする.

この時, もしをが小さ過ぎれば, 誤った向きの不等号の不 等式を採用する可能性が生じ，そのような場合他の不等式と 連立させると解は空集合となる．そのようなことが生じた場 合はをを斬増させ改めて不等式を導出することにすれば不等 号の逆転した不等式は順次取り除かれ, 最終的に正しい向き の不等号のみをもつ連立不等式が得ら札る。したがって連立 不等式が解を持つ最小のにが定まり, そのような連立不等式 について $m_{i}$ の解を求めることになる.

なお， $m_{i}$ については間隔尺度の範囲で数值化することを 考えるので原点と単位の取り方に任意性があるが, 適当な数 值解を得るため, 一般性を失うことなく次の式 (8), (9)の条 件を付け加える.すなわち BMPC 法での尺度付けは以下の 連立不等式を解くことに帰着される。

$$
\begin{gathered}
m_{j_{s}}-m_{i_{s}}-m_{l_{s}}+m_{k_{s}}>0, s \in\{1,2, \cdots, K\}(7) \\
\sum_{i=1}^{n} m_{i}=0 \\
\sum_{i=1}^{n} m_{i}^{2}=1
\end{gathered}
$$

ただし，Kは得られる連立不等式の個数である。

\section{2 解領域の表現}

連立不等式 (7) を行列表現すると

$$
\mathbf{A m}=\left[\begin{array}{c}
\mathbf{a}_{1} \\
\mathbf{a}_{2} \\
\vdots \\
\mathbf{a}_{k} \\
\vdots \\
\mathbf{a}_{K}
\end{array}\right]\left[\begin{array}{c}
m_{1} \\
\vdots \\
m_{n}
\end{array}\right]>0
$$

となる.Aは，これを係数行列と呼ぶが， $K \times n$ 行列であり， その成分である $\mathrm{n}$ 次元行べクトル $\mathrm{a}_{k}$ を係数べクトルと呼ぶ. $\mathrm{m}$ は $\mathrm{n}$ 次元列ベクトルであり, 各係数べクトルは 1 つの不等 式を代表している，以上の表記にしたがって，式 (8) と式 (9) 
を行列で表現すると，それぞれ，

$$
\begin{array}{r}
\mathbf{a}_{0} \cdot \mathbf{m}=[1,1, \ldots, 1] \cdot \mathbf{m}=0 \\
|\mathbf{m}|=1
\end{array}
$$

となる。

連立不等式 (10)の中の不等式の一つ

$$
\mathbf{a}_{k} \cdot \mathbf{m}=\left[a_{k_{1}} a_{k_{2}} \cdots a_{k_{n}}\right]\left[\begin{array}{c}
m_{1} \\
\vdots \\
m_{n}
\end{array}\right]>0
$$

の解は $\mathrm{n}$ 次元空間内で原点を通り $\mathbf{a}_{k}$ を法線とする超平面に よって定まる一つの開半空間である。したがって連立不等式 (10) と (11), (12) の解は, そ扎ら開半空間の共通領域であり Fig. 2 のように $\mathrm{n}$ 次元ユークリッド空間内の式 (10)を満た す超平面を境界面とし原点に頂点を有する凸多面錐の内点で, 原点からの距離 1 の点の集合となる.

この凸多面錐の各稜について原点から長さ 1 のベクトルを 稜ベクトルと呼び $g_{i}, i \in\{1, \cdots, r\}$ で表わす. また， $\mathbf{a}_{k}$ の中 からほかの係数ベクトルの非負線形結合で表わせないものを 抜き出し; $h_{j}, j \in\{1, \cdots, s\}$ と表わす。これは，式 (10) の 不等式の中から解領域を規定するのに必要十分な不等式を抜 き出すことに相当し，これらの $h_{j}$ を必要十分係数ベクトルと 呼ぶ.こ机によって解 (領域)はつぎのように表現できる。

$$
\begin{array}{r}
\left\{\mathbf{m}\left|\mathbf{a}_{0} \cdot \mathbf{m}=0, \mathbf{A m}>0,\right| m \mid=1\right\} \\
=\left\{\mathbf{m}\left|\mathbf{a}_{0} \cdot \mathbf{m}=0, \mathbf{H m}>0,\right| m \mid=1\right\} \\
=\left\{\mathbf{m}\left|\mathbf{m}=\sum_{i=1}^{r} \lambda_{i} g_{i}, \lambda_{i}>0,\right| m \mid=1\right\} \\
\text { ただし }, \mathbf{H}=\left(\begin{array}{c}
h_{1} \\
\vdots \\
h_{s}
\end{array}\right)
\end{array}
$$

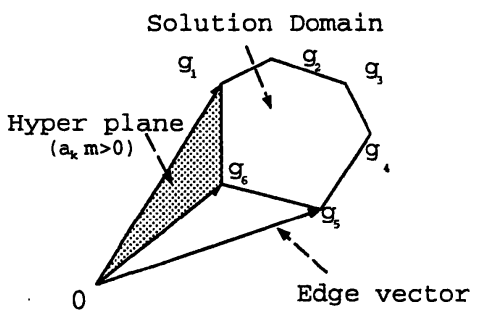

Fig. 2 Solution domain

\section{3 解を求めるアルゴリズムの概要 ${ }^{2}$}

以下に BMPC 法の解領域更新法における逐次的解領域更 新アルゴリズムを示すが，アルゴリズムは連立不等式を一挙 に解くのでなく，必要最小限の個数の連立不等式から適当に 初期解を求め, 以下，未考慮の不等式を 1 つ追加しては解領 域を更新する逐次的アルゴリズムになっている，これは，式 (7)の連立不等式には互いに矛盾する不等式が含まれること が多く，単純に式 (7) から解領域を求めると空集合になる危
険性があるためである，そこで，矛盾のない信頼のおける不 等式だけを選び出しつつ順次，解領域を更新する方法をとる。

(1) $\mathbf{a}_{k} \in\{1, \cdots, K\}$ の中から互いに独立な $n-1$ 個の 係数ベクトルを报き出し $\left\{{ }^{0} h_{j}\right\}$ とする。

$\left\{{ }^{0} h_{j}\right\}$ と $\mathbf{a}_{0}$ にっってできる正方行列の逆行列を求め, その 列べクトルの符合を変えたもののうち $\mathbf{a}_{0}$ と直交する $n-1$ 個を $g_{i}, i \in\{1, \cdots, n-1\}$ とし，その集合を $\left\{{ }^{0} g_{i}\right\}$ で表わ す.これにより初期解領域が決まり, $\left\{{ }^{0} g_{i}\right\}$ は初期解領域 を表現する稜ベクトルの集合となる，以降， $k$ 番目までの 不等式から得ら机る解領域を $\left\{{ }^{k} h_{j}\right\},\left\{{ }^{k} g_{i}\right\}$ によって与えら れるものとする。

(2) 次に, $k+1$ 番目の未考慮の係数ベクトル $\mathbf{a}_{k+1}$ を付 け加えることによって得られる解領域を求める。まず,

$$
p_{i}=\mathbf{a}_{k+1} \cdot g_{i}
$$

を計算し， $p_{i}$ が正，零，負に対応して $g_{i}$ をそれぞれ $g_{i}^{+}, g_{i}^{0}, g_{i}^{-}$に分類する.

\section{（3）（a） $\left\{g_{i}^{+}\right\}$が空集合の場合}

解は空集合となるため $\mathbf{a}_{\mathbf{k}+1}$ を係数べクトルとする不等 式が連立不等式に含まれなくなるまでとを增加させ改め て不等式を導出し，(1)に戻る.

（b） $\left\{g_{i}^{+}\right\}$が空集合でなく, $\left\{g_{i}^{-}\right\}$が空集合の場合 新しい係数べクトルは解領域を変化させないため, 解領 域の更新の必要はない。これは, 係数べクトル $\mathbf{a}_{k+1} に$ 対応する不等式がこの段階までに考虑された不等式につ いて圥長な不等式になっていることを意味する.

（c） $\left\{g_{i}^{+}\right\},\left\{g_{i}^{-}\right\}$がともに空集合でない場合 それまでの解領域は $\mathbf{a}_{k+1}$ によって二分される。このと き, どの $g_{i}^{+}$とも直交しない ${ }^{k} h_{j}$ は, 変更後の解領域を規 定するものではないため取り除き $\left\{{ }^{k+1} h_{j}\right\}$ は以下のよう になる。

$$
\begin{array}{r}
\left\{{ }^{k+1} h_{j}\right\}=\mathbf{a}_{k+1} \cup\left\{h \mid \in\left\{{ }^{k} h\right\},\right. \\
\left.\exists^{k} g_{i}^{+} \text {s.t. } h \cdot{ }^{k} g_{i}^{+}=0\right\}
\end{array}
$$

$\left\{{ }^{k} h_{j}\right\}$ の中の独立な $n-3$ 本の係数ベクトルと同時に直 交する $g^{-}, g^{+}$のすべての対に関して以下の式 (17), (18) を用いて新たな稜べクトル $g^{\text {new } っ く る . ~}$

$$
\begin{array}{r}
g^{\text {new }}=\left(\mathbf{a}_{k+1} \cdot g^{-}\right) \cdot g^{+}-\left(\mathbf{a}_{k+1} \cdot g^{+}\right) \cdot g^{-} \\
g^{\text {new }}=\frac{g^{\text {new }}}{\left|g^{\text {new }}\right|}
\end{array}
$$

これにより, 更新後の新しい解領域を記述する稜べクト ルの集合 $\left\{{ }^{k+1} g\right\}$ は

$$
\left\{{ }^{k+1} g_{i}\right\}=\left\{g^{+}\right\} \cup\left\{g^{0}\right\} \cup\left\{g^{\text {new }}\right\}
$$

となる。

（4）未考慮の係数べクトルがまだ残っていれば (2)に戻 る.

以下係数ベクトルをすべて考慮し尽くすまで逐次的に以上 を実行する。 


\section{3. 稜ベクトルの性質を考慮した解領域更新新ア ルゴリズム}

前章で説明したように，新たな係数ベクトルを考慮したと き, $\left\{g_{i}^{+}\right\}\left\{g_{i}^{-}\right\}$がともに空集合でなければ解領域は更新され る.これは，Fig. 3 に図示するように新たに考慮した係数べ クトルに対応する超平面が解領域を分断する場合を意味して いる.このとき，更新後の解領域の稜ベクトルはすべて改め て求める必要はなく，領域が切断されたことによって新たに 生じた稜ベクトルのみを求め机ばよい。また, 新しい解領域

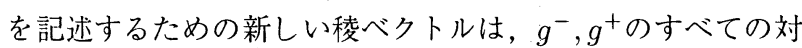
に対して求める必要はなく, $\left\{h_{i}\right\}$ の中の独立な $n-3$ 本の 係数ベクトルと同時に直交する $g^{-}, g^{+}$のすべての対に関して 新しい稜ベクトルを求め机ばよい. Fig. 3 を例にして言えば, $g_{1}^{-}$と $g_{6}^{+}$，および $g_{4}^{-}$と $g_{5}^{+}$の二組の対についてのみ考えるだ けでよい.これらの二組の対における $g^{-}, g^{+}$の関係を考える と, いず机も解領域の境界をなすある超平面に隣接して並ぶ 関係となっていることがわかる.

そこで, 本章では, 各稜ベクトルの特質の記述方法を工夫 することにより，稜ベクトル同士の位置関係の把握を容易に し，隣接して並ぶ稜べクトルの対を効率的に探し出すため方 法を提案する. 結果としてこのことにより効率的な解領域更 新法が実現される。

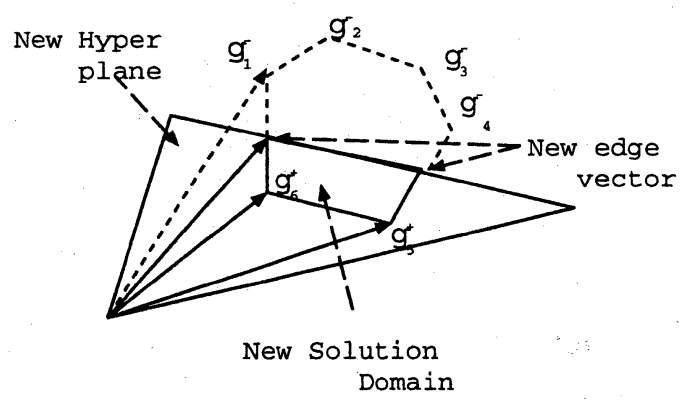

Fig. 3 Solution domain renewal

\section{1 稜ベクトルの特質の記述 ${ }^{5)}$}

解領域は, 式 (7) で表わされる $K$ 個の不等式の解の共通領 域であり，凸多面錐をなすがその稜線，つまり稜べクトルに ついて以下のようなことが指摘できる.すなわち, $n-1$ 次元 超平面同士の交わりによってできる空間は 1 次元減り $n-2$ 次元になり，ささらにその空間と超平面が交わることによって できる空間の次元はまた一つ次元が減ることになる。これを 繰返すことを考えると, 稜べクトルの次元は 1 次元であるか ら 1 つの稜べクトルは $n-2$ 個の超平面の交わりによってで きていることになる，このことを考慮すると，各稜べクトル の特質として以下のことが言える.

「稜ベクトル $g_{i}$ は， $\mathbf{a}_{0}=\{1, \cdots, 1\}$ と直交し，また同時 に一次独立な $n-2$ 個の係数べクトルとも直交している. し たがって，どの超平面の交線としてできたかによって各稜べ クトルの特質を記述することができる」
このとき, 各稜べクトル $g_{i}$ と直交する $\mathbf{a}_{0}$ 以外の $n-2$ 個 の係数ベクトルをその稜ベクトルの「登録係数ベクトル」と 呼び, 各稜ベクトルはすべて登録係数ベクトルによって特質 付けら机る。ただし，以降では，たとえべクトルとして全く 同じ稜ベクトルでも登録係数ベクトルが異なれば異なる稜べ クトルとし扱うことに注意する。これは，稜べクトルが直交 する $n-2$ の係数べクトルの組は 1 種類のみとは限らないた めである.

Table1に BMPC 法における稜ベクトルを記述するデー 夕構造を示す.

Table 1 Representative indexes of edge vector

\begin{tabular}{|l|l|}
\hline ID & The ID Number of Edge Vector \\
\hline Elements & Elements of Edge Vector. \\
\hline FaceList & $\begin{array}{l}\text { ID's of registered Hyper Planes which are } \\
\text { orthogonal to the EdgeVector. }\end{array}$ \\
\hline
\end{tabular}

\section{2 隣接稜ベクトル対の探索}

前節で述べた解領域更新アルゴリズムのとおり解領域更新 時, 新たな稜べクトルの計算が必要になるのは, 新しい係数 ベクトル $\mathbf{a}_{k+1}$ を加えたときに $\left\{{ }^{k} h_{i}\right\}$ の中の独立な $n-2$ 本 の係数ベクトルと同時に直交する $g^{-}, g^{+}$のすべての対に対し てである.このような対をなす 2 つの稜べクトルは互いに隣 接する稜べクトルであり，それぞれの登録係数ベクトルは 1 つを除き残りはすべて互いに共通する登録係数ベクトルをも つこととなる.

このため, 各稜べクトルについては, そのデータ構造の中 に直交する係数べクトルを登録係数ベクトルとして登録して 併せ記憶するものとする．ただしこの場合，係数ベクトルに は一貫番号が ID として付けられ，それら ID 番号の組を各 稜ベクトル固有の標識として活用することとする.

以上の準備の下に，ある稜ベクトル $g_{1}$ に隣接する稜ベクト ルの探索について考える. $g_{1}$ の標識, すなわちその登録係数 ベクトルの一貫番号の組を簡単化のため $\left[\delta_{1}, \delta_{2}, \ldots, \delta_{n-2}\right]$ と し, 係数ベクトル $\mathbf{a}_{k+1}$ を追加して考慮した時, 前章 2.3 内の アルゴリズムの概要 $(3)$ (c) の状況の下に, 解領域が分断され たとする。ここで, $\mathbf{a}_{k+1}$ のつ IDを $\delta_{n e w}$ とする.

$g_{1}$ と隣接する稜ベクトル $g_{2}$ の ID は, 登録係数ベクトルが 一つだけ違うことから $\left[\delta_{1}, \ldots, \delta_{i-1}, \delta_{i+1}, \ldots, \delta_{n-2}, \delta_{j}\right]$ と表わ すことができる.

ここで, 稜ベクトル $g_{1}$ の登録係数ベクトルの各 ID 番号の 総和を $S_{1}$ とする.

$$
S_{1}=\sum_{k=1}^{n} \delta_{k}
$$

一方 $S_{2}$ は $S_{1}$ を用いて

$$
S_{2}=S_{1}-\delta_{i}+\delta_{j}
$$

と表わされる。ここで, $g_{1}$ の登録係数ベクトルの番号は ID 番号の小さい順にソートされているとす机ば， $S_{2}$ が最小と なるのは $\delta_{i}=\delta_{n-2}, \delta_{j}=0$ のときで, $S_{2}=S_{1}-\delta_{n-2}$ とな 
る.一方連立に追加さ机る係数ベクトルの順を，その ID 番 号の小さい順に合わせるとすれば $\delta_{j}$ の最大は $\delta_{n e w}$ となるため, $S_{2}$ が最大となるのは $\delta_{i}=\delta_{1}, \delta_{j}=\delta_{n e w}$ のときで, 最大值は $S_{2}=S_{1}-\delta_{1}+\delta_{n e w}$ となる.したがって, $g_{1}$ に隣接する稜 ベクトルの ID 番号総和 $S_{s}$ は

$$
S_{1}-\delta_{n-2} \leq S_{s} \leq S_{1}-\delta_{1}+\delta_{n e w}
$$

の範囲にあることがわかる.

この点に着目すると, 登録係数べクトルの ID 番号総和に よってあらかじめ稜ベクトルをソートしておけば隣接稜べク トル探索の際その候補を大幅に減らすことができる.

\section{4. 不等式の追加順と計算効率の考察}

\section{1 不等式追加順による解領域更新経過の変化}

BMPC 法において最終的に定まる解領域を記述する不等 式の個数は一対比較行列から得られるすべての不等式の個数 の数パーセントにすぎない。これは，不等式の大部分が圥長 であることを意味している. 一方, 解領域の更新経過を分析 して見るとその更新回数は最終的な解領域を記述する不等式 の個数の数十倍にもおよぶことが多い。こ扎はうまり,工夫 す机ば省くことのできる更新作業を多数行なっていることを 示唆している.

そこで簡単化のため Fig. 4 に示されるような場合を例に とって考える. 図は, 新しい超平面 (不等式)を考慮すること によって解領域が実線で表わされる領域に更新されることを 示しているが, 同時に点線で表わされる 3 個の超平面に対応 する不等式が新しい不等式によって圥長な不等式になること も意味している，つまり，ここで追加した新しい不等式が先 に考慮されていれば省くことのできた解領域更新がここまで の段階までに少なくとも 3 回はあったことになる.

この考え方を進め机ば，最終的な解領域を記述する不等式 のみを当初から連立させてい㞦ば最も少ない更新回数で解領 域が得られるということになるが，実際にはどのような不等 式の組が最終的な解領域を記述する不等式なのかは最初には 不明である。

しかし，明らかに午長となる不等式を後の段階で考慮する ようにすれば，このことによって解領域の更新回数を減らす ことは可能となる.したがって, 次節では明らかにて長とな る不等式はどのような不等式かについて考察する.

\section{2 不等式追加順入れ替えのアルゴリズム}

まず，BMPC 法において作ら机る不等式は，不等式の形 式上次の 3 種類に分類される.

（1） 2 つの試料の尺度值の大小関係を直接示す不等式 (直接比較不等式)

$$
\varphi_{i j}-\varepsilon>\varphi_{j i} \Longleftrightarrow 2 m_{j}-2 m_{i}>0
$$

（2） 2 つの試料の尺度值の大小関係を他の試料に対する 比較から導出した不等式（間接比較不等式）

$$
\varphi_{i j}-\varepsilon>\varphi_{k j} \Longleftrightarrow m_{k}-m_{i}>0
$$

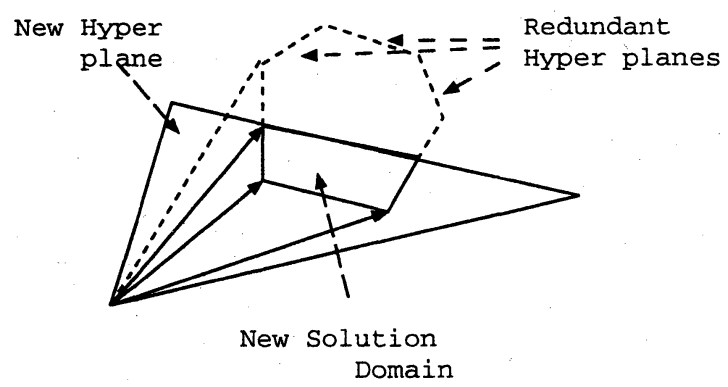

Fig. 4 Image of redundant inequalities

$$
\varphi_{i j}-\varepsilon>\varphi_{i k} \Longleftrightarrow m_{j}-m_{k}>0
$$

（3）その他の不等式（差分比較不等式）

$$
\begin{aligned}
\varphi_{i j}-\varepsilon>\varphi_{k l} & \Longleftrightarrow m_{j}-m_{i}-m_{l}+m_{k}>0(26) \\
\varphi_{i j}-\varepsilon>\varphi_{k i} & \Longleftrightarrow-2 m_{i}+m_{j}+m_{k}>0 \quad(27)
\end{aligned}
$$

なお, 直接比較不等式の形式は, 結果において間接比較不 等式と同じ形式になる.

ここで，次のような二つの直接 (または間接) 比較不等式

$$
\begin{aligned}
& m_{j}-m_{i}>0 \\
& m_{l}-m_{k}>0
\end{aligned}
$$

が存在する場合，以下の差分比較不等式

$$
m_{j}-m_{i}-m_{k}+m_{l}>0
$$

が存在する可能性はかなり高く，この不等式 (30) は不等式 (28)，(29) に対し常に圥長な不等式となる.したがって, 式 (28), (29) を先に考慮すれば解領域の更新回数を減らすこと が可能となる.

そこで，連立不等式に追加する不等式の順序を直接比較不 等式 $\rightarrow$ 間接比較不等式 $\rightarrow$ 差分比較不等式の順とすることと し，これによって処理時間の短縮を図る。

\section{5. 高速化された解領域更新新アルゴリズム}

本章では, 前章までに述べた, 稜べクトルの性質, および 不等式の連立順を考慮した解領域更新のための新しいアルゴ リズムの手順を以下に示す。

（1） $\mathbf{a}_{k} \in\{1, \cdots, K\}$ を直接比較, 間接比較, 差分比較 の順に並べ変える。

(2) $\mathbf{a}_{k} \in\{1, \cdots, K\}$ の中から互いに独立な $n-1$ 個の 係数べクトルを抜き出し $\left\{{ }^{0} h_{j}\right\}$ とする.

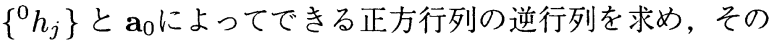
列べクトルの符合を変えたもののうち $\mathbf{a}_{0}$ と直交する $n-1$ 個を $g_{i}, i \in\{1, \cdots, n-1\}$ とし，その集合を $\left\{{ }^{0} g_{i}\right\}$ で表わ す。これにより初期解領域が決まり， $\left\{{ }^{0} g_{i}\right\}$ は初期解領域 を表現する稜べクトルの集合となる，以降， $k$ 番目までの 不等式から得られる解領域を $\left\{{ }^{k} h_{j}\right\},\left\{{ }^{k} g_{i}\right\}$ によって与えら れるものとする.

(3) 次に, $k+1$ 番目の未考慮の係数ベクトル $\mathbf{a}_{k+1}$ を付 
け加えることによって得られる解領域を求める。まず，

$$
p_{i}=\mathbf{a}_{k+1} \cdot g_{i}
$$

を計算し, $p_{i}$ が正, 零, 負に対応して $g_{i}$ をそれぞれ $g_{i}^{+}, g_{i}^{0}, g_{i}^{-}$に分類する.

\section{（4）（a ） $\left\{g_{i}^{+}\right\}$が空集合の場合}

解は空集合となるためをを増加させ再び不等式を導出し, (1)に戻る。

（b ） $\left\{g_{i}^{+}\right\}$が空集合でなく, $\left\{g_{i}^{-}\right\}$が空集合の場合 新しい係数べクトルは解領域を変化させないため, 解領 域の更新の必要はない.

(c) $\left\{g_{i}^{+}\right\},\left\{g_{i}^{-}\right\}$がともに空集合でない場合

それまでの解領域は $\mathbf{a}_{k+1}$ によって二分される。このと き, どの ${ }^{k} g_{i}^{+}$とも直交しない ${ }^{k} h_{j}$ は, 変更後の解領域を規 定するものではないため取り除き $\left\{{ }^{k+1} h_{j}\right\}$ は以下のよう になる

$$
\begin{array}{r}
\left\{{ }^{k+1} h_{j}\right\}=\mathbf{a}_{k+1} \cup\left\{h \mid \in\left\{{ }^{k} h\right\},\right. \\
\left.\exists^{k} g_{i}^{+} \text {s.t. } h \cdot{ }^{k} g_{i}^{+}=0\right\}
\end{array}
$$

$\left\{g_{i}^{+}\right\}$と $\left\{g_{i}^{-}\right\}$から一つずつ稜ベクトルを選び出し登録 係数ベクトルを調べ, $n-3$ 個の登録係数ベクトルが一 致していれば，二つの稜ベクトルは隣接する位置関係に

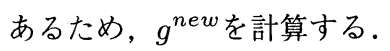

$$
\begin{array}{r}
g^{\text {new }}=\left(a_{k+1} \cdot g^{-}\right) \cdot g^{+}-\left(a_{k+1} \cdot g^{+}\right) \cdot g^{-} \\
g^{\text {new }}=\frac{g^{\text {new }}}{\left|g^{\text {new }}\right|}
\end{array}
$$

$g^{n e w}$ の登録係数ベクトルとして共通する $n-3$ 個の係数 ベクトルと $\mathbf{a}_{k+1}$ を登録する.すべての $\left\{g_{i}^{+}\right\}$と $\left\{g_{i}^{-}\right\}$の 組合せについて同様の操作を行なう.

以上により, 更新後の新しい解領域を記述する稜べク トルの集合 $\{g\}$ は

$$
\left\{{ }^{k+1} g_{i}\right\}=\left\{g^{+}\right\} \cup\left\{g^{0}\right\} \cup\left\{g^{n e w}\right\}
$$

となる。

(5) 登録係数ベクトルの ID 番号総和によって $\left\{{ }^{k+1} g_{i}\right\}$ をソートする.

（6）未考慮の係数ベクトルがまだ残っていれば (3)に 戻る.

（7） $\{g\}$ のそれぞれのベクトルの長さを 1 に正規化する.

\section{6. 高速化アルゴリズムの効果}

本章では, 高速化アルゴリズムによる新解法と従来法とに つき計算効率の比較を行なう. 人工的に作った一対比較表を 対象に計算を行ない, 解領域更新回数, 途中段階で現机る異 なる稜ベクトル数と処理時間，の観点から比較を行なった.

実験に用いた一対比較表は, 各試料に固有の得点を与え, その得点差の形で一対比較結果を与えたものである. なお, 各試料に与えられる固有の得点はランダムに与えられ, 試料 数 4 10 個でそ犳ぞれ 10 回ずつ異なる一対比較表を作成し た. Table 2はそのような一対比較表の一例である.なお,
Table 2 Example of paired comparison table

\begin{tabular}{|c|c|c|c|c|c|c|c|c|c|}
\hline $\mathrm{i} \backslash \mathrm{j}$ & 0 & 1 & 2 & 3 & 4 & 5 & 6 & 7 & 8 \\
\hline 0 & - & -82 & -66 & -36 & -55 & -6 & -8 & -55 & -80 \\
\hline 1 & 82 & - & 16 & 46 & 27 & 76 & 74 & 27 & 2 \\
\hline 2 & 66 & -16 & - & 30 & 11 & 60 & 58 & 11 & -14 \\
\hline 3 & 36 & -46 & -30 & - & -19 & 30 & 28 & -19 & -44 \\
\hline 4 & 55 & -27 & -11 & 19 & - & 49 & 47 & 0 & -25 \\
\hline 5 & 6 & -76 & -60 & -30 & -49 & - & -2 & -49 & -74 \\
\hline 6 & 8 & -74 & -58 & -28 & -47 & 2 & - & -47 & -72 \\
\hline 7 & 55 & -27 & -11 & 19 & -0 & 49 & 47 & - & -25 \\
\hline 8 & 80 & -2 & 14 & 44 & 25 & 74 & 72 & 25 & - \\
\hline
\end{tabular}

Table 3 Number of solution space renewals

\begin{tabular}{|c|c|c|}
\hline Num.of objects & new method & old method \\
\hline 4 & 12.4 & 20.0 \\
\hline 5 & 27.9 & 52.3 \\
\hline 6 & 52.1 & 114 \\
\hline 7 & 105 & 218 \\
\hline 8 & 171 & 380 \\
\hline 9 & 253 & - \\
\hline 10 & 375 & - \\
\hline
\end{tabular}

いずれの場合も試料数 9,10 に対する従来法の計算は, 処理 に時間がかかりすぎ計算が困難なため行なっていない．

Table 3は従来法と新解法による解領域更新回数の平均を 比べたものである．表を見れば，従来法に比較し，新アルゴ リズムでは, 解領域の更新回数が半分程度になっていること がわかる. また, 途中段階で現れる異なる稜ベクトルの総数 は Table 4のようであり, 試料数 8 の場合で稜ベクトル総数 は $1 / 4$ 程度に減っている. 試料数が増加すればするほどより 効果が期待でき，これによってメモリ容量を大幅に節約する ことが可能であると言える.

一方, 最終的な解領域を求めるまでの計算時間の平均は Table 5のようである. なお, 表中の () 内にその標準偏差 を示す。これら表からわかるとおり試料数が増えるにつれ高 速化の効果は大きく, 試料数を 8 にした場合は計算時間が $1 / 10$ 程度にまで短縮されている。この結果, 旧解法では処 理に時間がかかり過ぎ, 対応できなかった試料数の多い一対 比較デー夕についても解を求めることが可能となり, 多数の 試料を用いる検査に関する尺度付けに道を拓くものであるこ

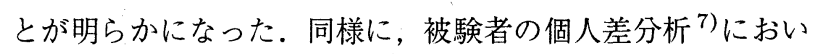
ても, 計算対象となる一対比較表の個数が多くなるため, 高 速化は大きな効果をもたらすものと期待できる.

Table 4 Number of appeared edge vectors

\begin{tabular}{|c|c|c|}
\hline Num.of objects & new method & old method \\
\hline 4 & 21.8 & 37.0 \\
\hline 5 & 122.9 & 285 \\
\hline 6 & 604 & 2176.4 \\
\hline 7 & 5040 & 17900 \\
\hline 8 & 34200 & 138000 \\
\hline 9 & 59500 & - \\
\hline 10 & 427000 & - \\
\hline
\end{tabular}


Table 5 Spent time compairison

\begin{tabular}{|c|c|c|}
\hline Num.of abjects & new method & old method \\
\hline 4 & $0.006 \sec (0.00)$ & $0.02 \sec (0.00)$ \\
\hline 5 & $0.021(0.00)$ & $0.03(0.00)$ \\
\hline 6 & $0.087(0.01)$ & $0.197(0.02)$ \\
\hline 7 & $0.74(0.23)$ & $4.01(0.72)$ \\
\hline 8 & $13.1(5.0)$ & $135(37.2)$ \\
\hline 9 & $29.6(7.8)$ & - \\
\hline 10 & $1954(2510)$ & - \\
\hline
\end{tabular}

\section{7. 結 論}

以上, 解領域を記述する稜べクトルの性質を分析し, デー 夕構造として「登録係数べクトル」を活用することを提案し， この方法により解領域更新時, 隣接稜ベクトルの探索が容易 になることを明らかにした．また，BMPC 法において不等 式を立てる際に圥長な不等式が数多くできることから，不等 式を連立不等式に追加する順番について考察し，直接比較不 等式および間接比較不等式を差分比較不等式に先行させる方 式を提案し，効率的な解領域更新が行なえることを実証した。 $2 つ の$ 新手法の導入により計算速度，必要メモリー容量は大 幅に改善され，これまで計算が困難であった個数の多い試料 に対する尺度付けの計算も容易に行なうことができるように なった。

\section{参 考 文 献}

1）小林, 芝田:一対比較のための非計量的手法. 計測自動制御学 会論文集, 14-2,189/195(1978)

2) 小林, 坂本:帯関数モデル型一対比較法のための数值処理法と その解領域. 計測自動制御学会論文集, 18-4,377/384(1982)

3) 小林, 坂本: 帯関数モデル型一対比較法であらわれる連立不 等式の誤差を含まない数值計算法. 計測自動制御学会論文集, 19-7,544/550(1983)

4) D.Avis and K.Fukuda:A Reverse searchfor enumeration. Discrete Applied Mathematics, 65,21/46(1996)

5）青木, 曹, 大川I, 小林：帯関数モデル型一対比較法による人間 感覚の数量化. 第 13 回センシングフォーラム資料, 141/146 (1996)

6）鳥海，大川，小林:BMPC 法に抢ける矛盾不等式排除方法と 高速化処理アルゴリズム. 第 38 回 SICE 学術講演会予稿集, 639/640 (1999)

7）鳥海, 大川, 小林：BMPC 法に㧈ける評価関数を用いた被験 者の選別. 第 39 回 SICE 学術講演会予稿集, 講演番号 202A$3(2000)$

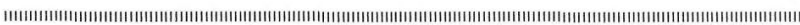

$$
\text { [著者紹 介] }
$$

鳥 海 不二夫 (学生会員)

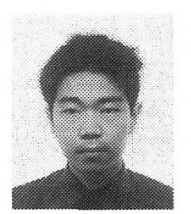

2001 年, 東京工業大学大学院理工学研究科制 御工学専攻修士課程修了, 同年同大学院理工学研 究科機械制御システム専攻博士課程入学, 現在に 至る。
曹

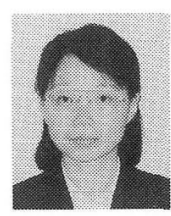

麗 (正会員)

1992 年, 東京工業大学大学院博士課程修了. 同 年花王 (株) 入社. 94 年東京工業大学助手. 98 年 より中国清華大学 自動化系 副教授, 現在に至る。 空間フィルタリング計測法, 官能検査, 多次元信 号処理およびセンサ応用の研究に従事. 88 年度本 学会学術奨励賞受賞 (工学博士).

\section{大山真 司 (正会員)}

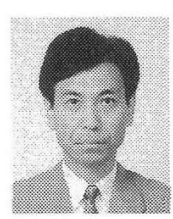

1984 年, 東京工業大学大学院修士課程修了. 同 年 (株) 日立製作所日立研究所入社. 90 年, 東京 工業大学工学部助手, 現在, 同学大学院理工学 研究科助教授. 計測工学, 計測システム構成論等 9研究，教育に従事. 86 年度本学会論文賞受賞. IEEE，電子情報通信学会の会員 (工学博士).

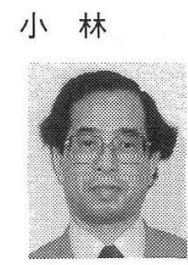

涁（正会員）

1969 年, 東京工業大学大学院博士課程修了. 同 年東京工業大学助手. 87 年同教授, 現在に至る。 計測用空間フィルタ, 感覚計測, 解領域法による 信号処理, 信号場, 高 SN 比計測法などの研究に 従事. $73,80,86$ 年度本学会論文賞受賞. 本会 フェロー (工学博士).

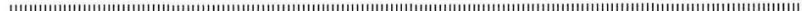

